\title{
Chloride Control and Monitoring Program in the Wichita River Basin, Texas, 1996-2009
}

Water resources of the Wichita River Basin in north-central Texas are vital to the water users in Wichita Falls, Tex., and surrounding areas. The Wichita River Basin includes three major forks of the Wichita River upstream from Lake Kemp, approximately 50 miles southwest of Wichita Falls, Tex. The main stem of the Wichita River is formed by the confluence of the North Wichita River and Middle Fork Wichita River upstream from Truscott Brine Lake. The confluence of the South Wichita River with the Wichita River is northwest of Seymour, Tex. (fig. 1). Waters from the Wichita River Basin, which is part of the Red River Basin, are characterized by high concentrations of chloride and other salinity-related constituents from salt springs and seeps (hereinafter salt springs) in the upper reaches of the basin. These salt springs have their origins in the Permian Period when the Texas Panhandle and western Oklahoma areas were covered by a broad shallow sea. Over geologic time, evaporation of the shallow seas resulted in the formation of salt deposits, which today are part of the geologic formations underlying the area. Groundwater in these formations is characterized by high chloride concentrations from these salt deposits, and some of this groundwater is discharged by the salt springs into the Wichita River (Keller and others, 1988).

\section{History of Chloride Control in the Wichita River Basin}

In 1957, the U.S. Public Health Department (now the U.S. Department of Health and Human Services) and U.S. Army Corps of Engineers (USACE) investigated the sources of the high chloride concentrations in the Red River Basin and identified 10 major source areas of chlorides and other salinity-related constituents in the Red River Basin, including several headwater areas in the Wichita River Basin. Three of the 10 source areas with high chloride concentrations and other salinity-related constituents (salt springs), designated by USACE as areas VII, VIII, and X, are along the three major forks of the Wichita River upstream from Lake Kemp (fig. 1). The Red River Chloride Control Project was implemented by Congress in 1959, who directed the USACE to develop a plan to control the natural chloride discharges from the high chloride source areas (Keller and others, 1988).

In 1974, the Water Resources Development Act granted authorization and funding for the USACE to construct chloride control structures at area VIII on the South Wichita River (fig. 1). Completed in 1987, the chloride control structure for area VIII consists of an inflatable, 5-foot-high, low-flow collection dam installed across the stream to capture saline water at low flows (fig. 2). The pooled, highly saline water is pumped to a pipeline and transported 23 miles to the Truscott Brine Lake, where much of it evaporates (fig. 3).

In 1991, construction of another low-flow collection dam began at area $\mathrm{X}$, located on the Middle Fork Wichita River (fig. 4). The inflatable dam and a pump station facility are in place, but the pipeline from area $\mathrm{X}$ to Truscott Brine Lake has not been completed. Salt deposits accumulate on the main channel bed upstream from the inflatable dam,

Figure 1. Location of sampling sites and salt spring areas, Wichita River Basin, Texas, 1996-2009. 


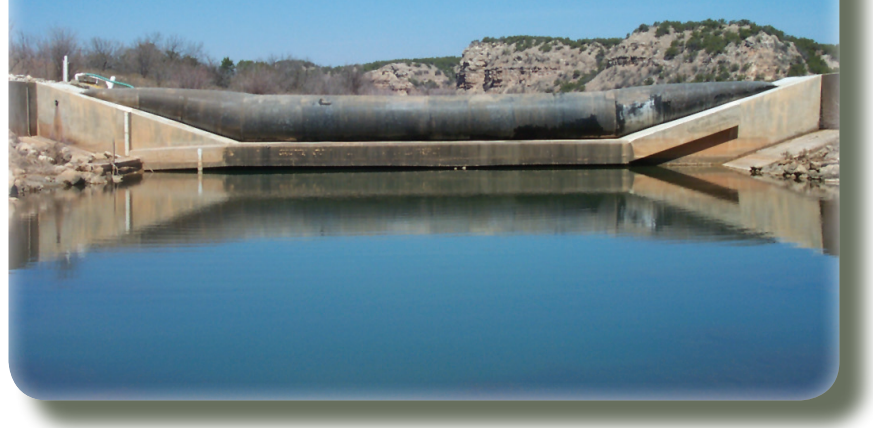

Figure 2. Upstream view of inflated low-flow collection dam, South Wichita River near Guthrie, Texas.

which was deflated at the time the photograph in figure 4 was taken. Construction of control structures at area VII has not been initiated.

\section{Description of Monitoring Program}

The U.S. Geological Survey (USGS), in cooperation with the USACE, established a network of eight continuous monitoring sites (table 1) in October 1995 to measure streamflow, temperature, and specific conductance in the Wichita River Basin. Discrete samples are collected periodically at the eight streamflow-gaging stations and analyzed for chloride. The chloride and streamflow data were used to develop regression curves for computing chloride loads in the Wichita River. These data were used to evaluate the effectiveness of the low-flow collection dam in reducing the amount of chloride in the Wichita River.

\section{Streamflow}

Water surface elevations were measured every 15 minutes from stage sensors at each of the gaged stream sites (fig. 1). These values were transmitted hourly from each location

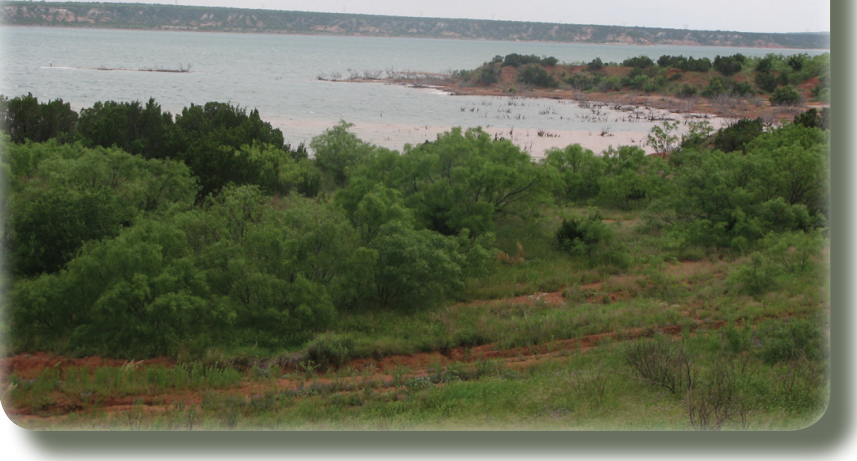

Figure 3. Truscott Brine Lake near Truscott, Texas.

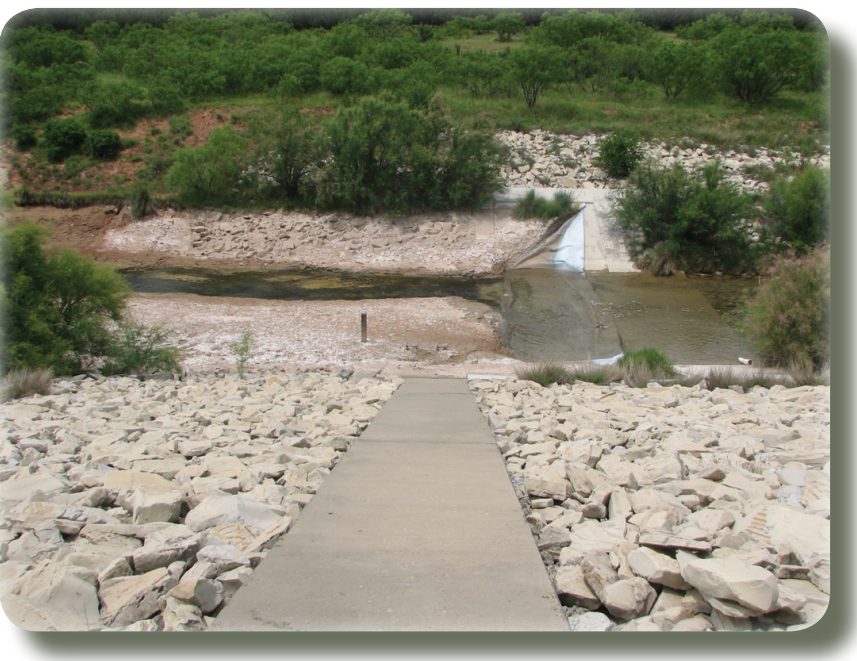

Figure 4. Accumulation of salt deposits on the channel bed of the Wichita River Basin upstream from the inflatable dam on the Middle Fork Wichita River.

Table 1. Median streamflow, median specific conductance, and chloride concentrations at U.S. Geological Survey streamflow-gaging stations in the Wichita River Basin, Texas, 1996-2009.

[mi ${ }^{2}$, square miles; $\mathrm{ft}^{3} / \mathrm{s}$, cubic feet per second; $\mu \mathrm{S} / \mathrm{cm}$, microsiemens per centimeter at 25 degrees Celsius; mg/L, milligrams per liter; NA, not applicable.]

\begin{tabular}{|c|c|c|c|c|c|}
\hline $\begin{array}{c}\text { Site } \\
\text { no. } \\
\text { (fig. 1) }\end{array}$ & USGS station number and name & $\begin{array}{c}\text { Drainage } \\
\text { area } \\
\left(\mathrm{mi}^{2}\right)\end{array}$ & $\begin{array}{c}\text { Median } \\
\text { streamflow } \\
\left(\mathrm{ft}^{3} / \mathbf{s}\right) \\
\end{array}$ & $\begin{array}{c}\text { Median specific } \\
\text { conductance } \\
(\mu \mathrm{S} / \mathrm{cm})\end{array}$ & $\begin{array}{c}\text { Median chloride } \\
\text { concentrations } \\
(\mathrm{mg} / \mathrm{L})\end{array}$ \\
\hline 1 & 07311600 North Wichita River near Paducah, Tex. & 540 & 10.0 & 23,100 & 6,890 \\
\hline 2 & 07311630 Middle Fork Wichita River near Guthrie, Tex. & 50.3 & 4.8 & 12,300 & 3,280 \\
\hline 3 & 07311700 North Wichita River near Truscott, Tex. & 937 & 17.0 & 17,400 & 5,200 \\
\hline 4 & 07311782 South Wichita River at Low Flow Dam near Guthrie, Tex. & 223 & ${ }^{1} 6.6$ & 45,700 & 18,740 \\
\hline 5 & 07311783 South Wichita River below Low Flow Dam near Guthrie, Tex. & 223 & .06 & ${ }^{2} \mathrm{NA}$ & 15,100 \\
\hline 6 & 07311800 South Wichita River near Benjamin, Tex. & 584 & 1.9 & 11,800 & 2,840 \\
\hline 7 & 07311900 Wichita River near Seymour, Tex. & 1,874 & 25.0 & 11,500 & 3,200 \\
\hline 8 & 07312100 Wichita River near Mabelle, Tex. & 2,086 & ${ }^{3} 1.6$ & 4,880 & 1,120 \\
\hline
\end{tabular}

${ }^{1}$ Streamflow measured at this gaging station represents diversions through pipeline to Truscott Brine Lake.

${ }^{2}$ Continuous records of specific conductance data are not collected.

${ }^{3}$ Streamflow regulated by releases from Lake Kemp. 
via satellite to the USGS National Water Information System (NWIS). Water surface elevations were used to compute discharge at all locations except site 4 , where diversions for chloride control were measured by a flow totalizer on the pipeline (Brent A. Vanderpol, Truscott Brine Lake Civil Engineer Technician, oral commun., 2011). Discrete stream discharge measurements were made by USGS personnel throughout the range in stage at each gaged site. Streamflow measurements and surface-water record computations were done by following the USGS Texas Water Science Center surface-water quality assurance plan and methods outlined by Rantz and others (1982a, b). Ratings for determining streamflow were developed from a database of measurements made at each location. Streamflow was computed by applying collected real-time stream-gage height information to discharge rating information. Daily mean discharge values are published in the USGS NWIS (U.S. Geological Survey, 2009).

The upper reaches of the Wichita River Basin consist of small, perennially flowing streams less than 20 feet wide and 1 foot deep during base flow. During base flow, the salt springs have a measurable effect on streamflow and water quality in the Wichita River Basin. For example, flow is continuous at site 1 near area VII during the dry summer months because of inflows from the springs. Compared with other sites in the study area, the amount of flow measured at sites 1 and 2 on the North and Middle Fork Wichita Rivers is disproportionately large compared to the size of the drainage areas gaged by these sites (table 1).
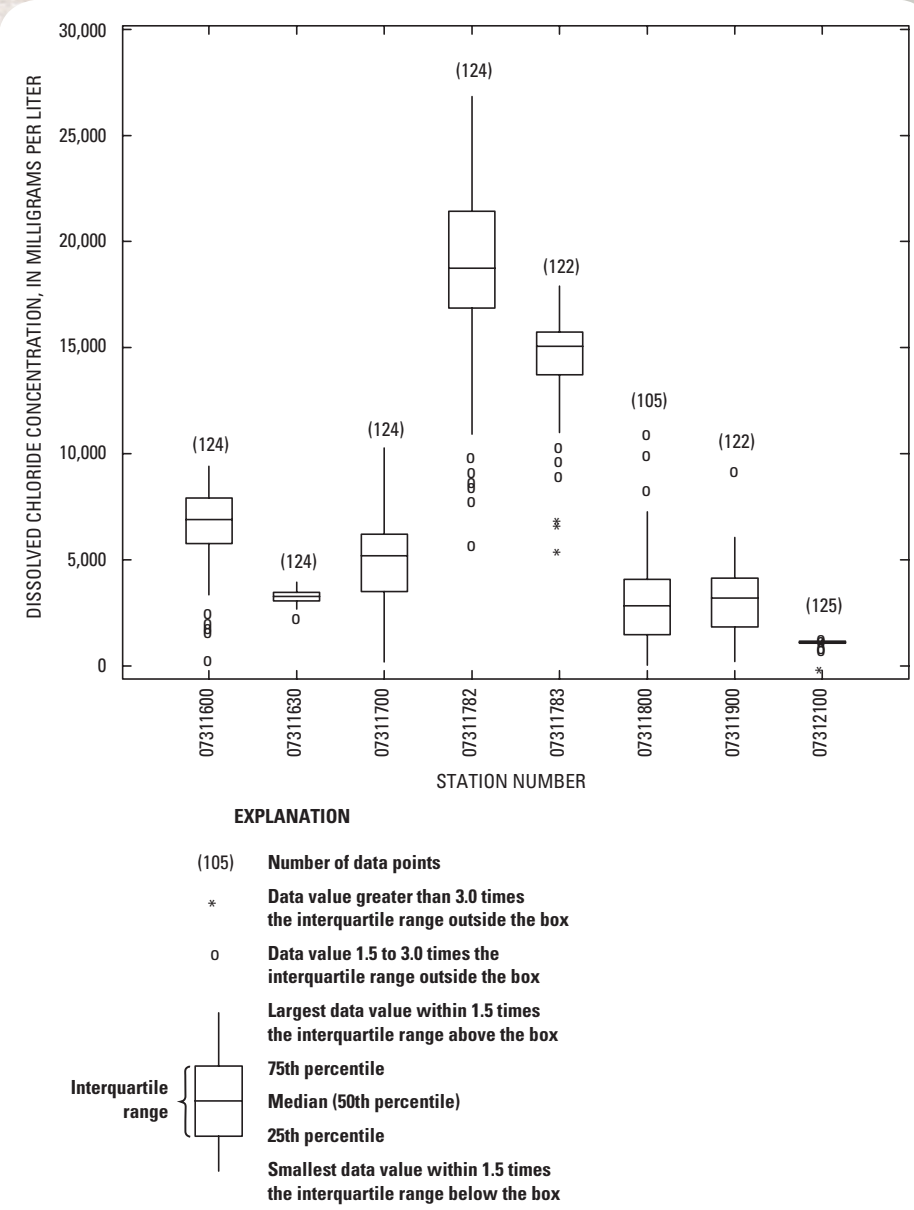

Figure 5. Boxplots depicting chloride concentrations at sampling sites in the Wichita River Basin, 1996-2009.
Streamflow of the South Wichita River is affected by the control structure (low-flow collection dam). The median discharge at site 5 , which is immediately downstream from the control structure, is 0.06 cubic foot per second; 6-7 cubic feet per second of the brackish headwaters of the South Wichita River are impounded and diverted to the Truscott Brine Lake (U.S. Geological Survey, 1983-98). The drainage area gaged by site 6 on the South Wichita River is 584 square miles, yet the median streamflow measured at site 6 is only 1.9 cubic feet per second (table 1). The stream is dry throughout much of the year at this site, which is downstream from chloride control structures.

\section{Discrete Water-Quality Sampling}

Discrete water-quality samples were collected every 4 to 6 weeks at each of the streamflow-gaging stations (sites 1-8) (fig. 1). The samples were analyzed for major ions, nutrients, and trace metals at the National Water Quality Laboratory (NWQL) in Denver, Colo., with the exception that starting in May 2003, the selenium analyses were done by the USGS laboratory of the Geologic Discipline in Denver, Colo. Methods for the collection of the samples followed the procedures outlined in the USGS National Field Manual, chapter A4 (U.S. Geological Survey, variously dated). Quality-control samples, such as field and equipment blanks, and duplicate samples were collected in order to maintain quality assurance. All data from the discrete environmental samples, including results for quality-control samples, were published in NWIS (U.S. Geological Survey, 2009).

Boxplots (fig. 5) show the range of dissolved chloride concentrations for the gaged stream sites during 1996-2009. The secondary maximum contaminant level for chloride, established by the "Texas Surface Water Quality Standards" for surface-water bodies designated for public water-supply use, is 300 milligrams per liter (Texas Commission on Environmental Quality, 2003). Median chloride concentrations were highest at the South Wichita River station 07311782 near area VIII, and lowest values were at station 07312100 (fig. 5).

\section{Continuous Water-Quality Monitoring}

Because water quality in the Wichita River Basin can vary considerably, the USGS used continuous water-quality monitors in addition to discrete sample collection. The waterquality monitors, installed at the gaged sites in the upper Wichita River Basin, were equipped with sensors that measure specific conductance and temperature. Site 5 was the only gaged site in which a continuous water-quality monitor was not installed (table 1). Water temperature and specific conductance values were collected every 30 minutes and transmitted hourly through a satellite system to NWIS. The continuous waterquality monitors were maintained by frequent checks with verified standards by following guidelines and standard procedures (Wagner and others, 2006). The sensors require careful field observation, cleaning, and calibration. Detailed procedures for the computation and publication of the data are followed (Wagner and others, 2006).

Specific conductance generally has an inverse correlation with discharge (fig. 6). USACE uses data collected by the 
USGS at the gaged sites to help determine when to deflate the dam at site 5. Depending on the measurements of specific conductance at site 5 , the dam is often deflated by USACE during periods of high flow to allow runoff from storms to continue downstream.

\section{Chloride Load Computations}

Keller and others (1988) first used daily mean discharge and daily mean specific conductance concentrations to compute loads (the weight per unit time of a constituent material transported by, suspended in, or deposited by water) for the USGSmonitored chloride-control sites in 1968. Baldys and others (1995, p. 5) wrote:

To compute loads, daily discharge and concentrations of dissolved solids and dissolved chloride at the streamflow-gaging stations are needed. Daily discharge data are available from continuous streamflow records. However, only periodic constituent concentration data are available [in the Wichita River Basin]. Because dissolved solids and dissolved chloride concentrations are highly correlated with specific conductance, and continuous specific conductance data are available for [selected] streamflow-gaging stations, regression equations that relate constituent concentrations to specific conductance can be used to obtain estimates of daily constituent concentrations from specific conductance.

Where data were sufficient to support the computation, dissolved chloride loads at each gaged site in the basin were estimated and published in the USGS Texas Water Science Center annual water-data reports (U.S. Geological Survey, 1983-98). The computation of chloride loads was done with regression curves and procedures developed by the USGS Texas Water

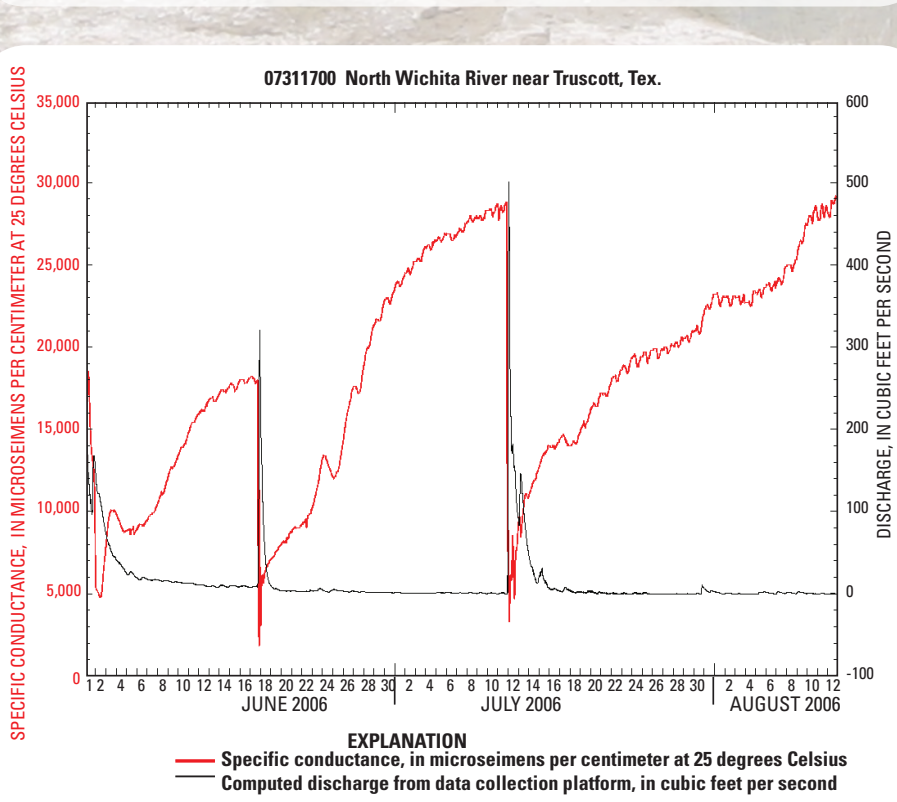

Figure 6. Continuous specific conductance and discharge data at the North Wichita River near Truscott, Texas, June 1 to July 12, 2006.
Science Center (Freeman L. Andrews, U.S. Geological Survey, written commun., 2000). Chloride load data were used by the USACE to measure the effectiveness of the low-flow collection dam on the removal of chloride from the Wichita River.

\section{References Cited}

Baldys, Stanley, III, Bush, P.W., and Kidwell, C.C., 1995, Effects of low-flow diversions from the South Wichita River on downstream salinity of the South Wichita River, Lake Kemp, and the Wichita River, North Texas, October 1982September 1992: U.S. Geological Survey Water-Resources Investigations Report 95-4288, 23 p.

Keller, Jack, Rawson, Jack, Grubb, Hubert, Kramer, Jackson, and Sullivan, Glenn, 1988, Report on the evaluation of the effectiveness of operation of area VIII Red River Chloride Control Project: Red River Chloride Control Project Report, $35 \mathrm{p}$.

Rantz, S.E., and others, 1982a, Measurement and computation of streamflow-Volume 1, Measurement of stage and discharge: U.S. Geological Survey Water-Supply Paper 2175, p. 1-284.

Rantz, S.E., and others, 1982b, Measurement and computation of streamflow-Volume 2, Computation of discharge: U.S. Geological Survey Water-Supply Paper 2175, p. 285-631.

Texas Commission on Environmental Quality, 2003, Guidance for assessing Texas surface and finished drinking water-quality data, 2004: accessed August 11, 2008, at http://www.tceq.state.tx.us/assets/public/compliance/monops/ water/04twqi/04_guidance.pdf.

U.S. Geological Survey, variously dated, National field manual for the collection of water-quality data: U.S. Geological Survey Techniques of Water-Resources Investigations, book 9, chaps. A1-A9, accessed June 2009, at http://pubs. water.usgs.gov/twri9A.

U.S. Geological Survey, 1983-98, Water resources data, Texas, water years 1982-97-Volume 1: U.S. Geological Survey Water-Data Report TX-82-1, TX-83-1, TX-84-1, TX-85-1, TX-86-1, TX-87-1, TX-88-1, TX-89-1, TX-90-1, TX-91-1, TX-92-1, TX-93-1, TX-94-1, TX-95-1, TX-96-1, TX-97-1.

U.S. Geological Survey, 2009, National Water Information System: accessed May 2009, at http://waterdata.usgs.gov/tx/ nwis/.

Wagner, R.J., Boulger, R.W., Jr., Oblinger, C.J., and Smith, B.A., 2006, Guidelines and standard procedures for continuous water-quality monitors-Station operation, record computation, and data reporting: U.S. Geological Survey Techniques and Methods 1-D3, 96 p.

-M.M. Haynie, G.F. Burke, and Stanley Baldys III
For additional information contact:

Director, Texas Water Science Center

U.S. Geological Survey

1505 Ferguson Lane

Austin, Texas 78754-4501

World Wide Web: http://tx.usgs.gov/ 